\title{
Teaching Narrative Text Using TAI Method To Increase Students' Writing Ability
}

\author{
Rahmanita Zakaria ${ }^{1}$, Muhammad Hasyimsyah Batubara ${ }^{2 *}$, Kurniati Bukit ${ }^{3}$ \\ 1,2,3 IAIN Takengon, Aceh Tengah, Aceh, Indonesia \\ ${ }^{1}$ zrahmanita@gmail.com*; 2,3 muhammad.hasyimsyahbatubara@gmail.com \\ * corresponding author
}

\section{ARTICLE INFO}

\section{Article history}

Received 20 September 2021

Revised 05 November 2021

Accepted 10 December 2021

Keywords

Keyword_1 Teaching

Keyword_2 Narrative

Keyword_3 Writing

Keyword_4 TAI

\section{ABSTRACT}

The research is the teaching narrative text using team assisted individualization (TAI) method to increase students' writing ability at second years SMPN 31 Takengon. The researcher used quantitative research with experimental design. The second year of SMPN 31 Takengon (VIII1 and VIII2) as the sample. Technique data analysis in this investigation uses statistics with the score t-test and formulate uses to compare the actual difference between control and experimental samples. The result of the using the team-assisted individualization (TAI) method is increase the students' writing in narrative text. It can be seen from the result of test tobs > ttable value tobs 2.88 and ttable 1,60 or tobs $\geq$ ttable. The team-assisted individualization (TAI) method also helps the students increase imagination and make the students easy to write in narrative text.

This is an open access article under the CC-BY-SA license.

\section{INTRODUCTION}

We know that language is very closely related to human life. It is one of the most main things to communicate. It is used as a connecting tool between people and between countries in this world. As a worldwide language, English is very ruling and has many links with all aspects of human life. English has many functions for a global society, such as communication, information transmission, teaching and learning process, economics, politics, etcetera. In general, language has two models that associate its functions, namely in spoken speech and in written form. Oral language is one form of human communication in the majority. In this form, the spoken words come from a large number of vocabularies that come out or through the mouth.

All words come from a limited set of vowels and consonants. We must assemble what we want to say into phrases and sentences arranged in syntax. Its vocabulary and syntax and its phonetics define it as a specific natural language. While the form of language in writing is a language that is rarely used in people's daily lives. Writing is only done to represent productive and expressive activities. In this written language activity, the writer must be good at using words or vocabulary in language structures in handwritten or typed form (Tarigan, 1994).

Ideas expressed in written form are more effective than words because ideas are poured into paper or online media, and when someone forgets, the idea can be re-read from 
the media that the author has created. Similarly, people who read will be easier or faster to understand because it can be read repeatedly. To produce writing requires accuracy, coherence, folding, and logic from one sentence to another, from one paragraph to the next, to form a good and complete article.

It is undeniable that writing is one of the most strenuous skills for students. The difficulty lies in create and organizing ideas and display those ideas into readable text. Another unfortunate situation is that students may feel bored because they are too lazy to think and write many sentences when the teacher gives homework. In the case of facing students' writing difficulties, as a teacher, it is important to think about how to improve students' writing skills. It is important to apply the right method in writing, one of which is the team-assisted individualization (TAI) method. According to Istarani \& Ridwan (2014; 2015), the team-assisted individualization (TAI) method is a collaborative learning method that emphasizes individual abilities, where individuals have different abilities and are used in groups. The teacher asks students to think about the specifics of the topic, cooperate with other students to discuss their ideas, and then the teacher personally tries. This method requires the active participation of teachers and students. In other words, the success of using this method depends on the user.

From the above background, researchers are interested in learning how to use the TAI method so that students can write well and make students interested in writing. This kind of method can encourage students to participate in understanding story ideas that will be included in narrative texts. It makes students more motivated to develop their potential and abilities in writing stories or narrative texts. On this occasion, the researcher will research the teaching narrative text using team assisted individualization (TAI) method to increase students' writing ability at second years SMPN 31 Takengon.

\section{LITERATURE REVIEW}

\subsection{Writing}

When a cultural shift occurs, the need for a new communication model is also needed. Written communication appears in society when spoken language cannot be used as a more detailed and formal means of communication (Halliday, 1985; Nunan, 1999). Writing is an effort to create, skills or thought processes to construct ideas into products that are reflected in written form clearly as sentences or paragraphs (Brown, 2001; Boardman, 2002; Nunan, 2003; Harmer, 2004 in Batubara, et al., 2021; Batubara, et al., 2021). In the academic world, writing is a real demand that must be mastered, and writing is a means for students to pay attention and practice certain language points (Penny, 1996). According to Neman (1989), writing is a single process in three stages, namely prewriting, writing, and rewriting, while Nunan $(1991 ; 2003)$ explained that writing is a very complex cognitive activity, and accuracy is needed simultaneously with many variables including content, format, sentences, structure, vocabulary, punctuation, spelling. Apart from being limited to composing sentences, writers must be able to organize information and integrate them into coherent paragraphs and texts (Nunan, 1991).

From the upstairs definition, the investigator can conclude that writing is rooted in ideas and words, and written communication refers to handwriting and spelling idioms' mental and physical abilities, through the investigator point of view, writing is the process of writing words into an essay. 


\subsection{Text}

Text is a unit of language that expresses meaning based on context. The text does not measure the number and limitations of the sentences and pages in its manufacture but expresses the meaning and completeness of the context (Wiratno, 2013). From this definition, the researcher can conclude that the text is a description that can be stated or written by someone in detail so that the reader can understand the author's creative process.

\subsection{Narrative Text}

Narrative texts aim to entertain listeners or readers related to imaginary experiences or complex events that lead to crises and finally find solutions. In Pardiyono's view (2007), narrative text is very suitable for telling past activities or events, highlighting experiences and problem solving, entertaining, and often intended to bring lessons to the reader. Narratives tell of major conflicts that usually involve humans and are resolved by suggesting messages about human values, feelings, or attitudes (Neman, 1989). It can be deduce from the theory above that narrative texts are stories that tell fantasy or stories from the past. Someone usually expressed in humans, these narrative texts are for entertainment and often for readers as a moral lesson.

Furthermore, Wiratno (2003) narrative text serves as a medium to show past experiences. Narrative texts talk about events by using the word events or events that occurred in the past tense. Through the previous definition, the investigator concludes that narrative text is the last story that happened, the story can be written about everyone, and narrative usually contains people's experiences. Moreover, narrative texts that tell of these past events can be in the form of legends, history, and fables.

\subsection{Team Asissted Individualisation Method}

TAI was originally initiated by Robert E. Slavin, a concept that combines cooperative learning and individual learning (Dumont et al., 2010). Robert E. Slavin (1997; 2005 ; 2008; 2010) explained that the TAI method is a learning method in which students are divided into groups with different or heterogeneous abilities. Each group consists of four members, and the group will receive a prize (Dumont et al., 2010). The team-assisted Individualization (TAI) method is a collaborative learning method that emphasizes individual abilities, where individuals with different abilities are different and distributed in a group whose goals can work together to achieve learning objectives.

The team-assisted individualization (TAI) method steps are as follows: a) The teacher conveys the learning objectives to be achieved and encourages students to study more actively. b) The teacher presents information in the form of a lecture. c) The teacher forms groups consisting of students with heterogeneous abilities. The basic function of this group is to perform classification tests or use pre-existing data. d) The teacher guides each group and supervises the discussion as needed. e) The teacher evaluates learning outcomes based on the material studied by students. f) The teacher looks for efforts related to student success (Istarani, 2011).

The explanation above, the researcher can conclude that the Team Assisted Individualization (TAI) method is a method used for group learning, and the group is organized and selects students with different abilities. One group consists of four people, and awards must be given so that students enjoy learning English. 


\section{RESEARCH METHODOLOGY}

\subsection{Research Design}

The researcher used quantitative research with experimental design. Quantitative is research with many claiming to apply for numbers, starting from collecting, interpreting the data, and appearance from its result (Arikunto, 2006).

\subsection{Sources of the Data}

a. Population

The population is all subject involved in the experimentation (Arikunto, 2006). So, the population in this investigation is all students in the second year at SMPN 31 Takengon. Amount 32 (thirty-two) students.

b. Sample

The sample is part of the population (Arikunto, 2006). The researchers used a random sampling technique to get the sample, where each individual has some opportunity. The second year of SMPN 31 Takengon is homogenous, where is each class gets the same study. So the researcher gets VIII ${ }^{1}$ and VIII $^{2}$ as the sample.

\subsection{Techniques of Data Collection}

Collecting data is one of the most main steps. There were some techniques of data collecting used, namely, observation and test. The aims of using these techniques were to know the students' responses during the activities, to see their abilities in mastering writing narrative text and their progress in gathering information.

\subsection{Data Analysis}

Technique data analysis in this investigation uses statistics with the score t-test: Sugiono (2009) formulate uses to compare the actual difference between control and experimental samples.

\subsection{The Assessment of Writing}

According to Kusaeri dan Suprananto (2012), assessment or rubric scoring is a scoring guide that describes the desired criteria in judging or giving teachers the level of students' work.

\subsection{The Criteria of Success}

Based on calculating of the data above, the researcher will get the students to result in test, wherever the success of this research will depend on the criteria the minimal success score (KKM), here based on the curriculum on the school, the criteria of success students English competencies there is 65 . Based on it, the students get a good score if they get that score.

\section{FINDINGS}

\subsection{The Result of the Observation}

In this research, the researcher had done the observations during teaching-learning activity in the classroom. The observation was done to get the information about students' expertise in writing narrative text using team assisted individualization (TAI) method.

However, in this observations, when the English teacher of the second year of SMP N 31 Takengon, Mrs. Leni Wardani, teaches their students, the researcher takes the time for observation. Based on observations, the researcher found that many students of the 
second year SMP N 31 Takengon are interested in using Team Assisted Individualization

(TAI) method in writing.

The result of observation in this research can be seen as follows:

a. The students come on time into the classroom, because the lesson will begin if all students enter the classroom.

b. The students give attention when the teacher gives the material about narrative text. If the student's attention to the teacher, of course, the study will enjoy because when the teacher explains the purpose and content of teaching material, they felt enjoy listening all of the explanation.

c. The teacher prepares the material about the topic that will be written.

d. The students choose the topic that will be written. Depending on the observation during the teaching implementation by using the team assisted individualization (TAI) method in writing narrative text, the student is interested in choosing the topic.

e. The students try to make narrative text using team assisted individualization (TAI) method

f. The students were enthusiastic in writing narrative text using TAI method. The students always gave positive respect for the teaching material and the target of learning that should be gained.

g. The students enjoy writing narrative text using TAI method, because TAI is a method freely and relaxing when the students write.

h. The students feel difficulty in writing narrative text using TAI method. When the students wrote the narrative text, they felt very difficult because, in the teaching and learning process, they were less about vocabulary and grammar in writing.

i. The students understand about narrative text-based team assisted individualization method, and It can be seen that when the student makes a task, the students can increase their writing.

j. The students give the responsibility toward the team assisted individualization (TAI) method in learning writing narrative text.

$\mathrm{k}$. The students can understand the lesson, because in the teaching and learning process, the students enjoy and are enthusiastic when the students write and can increase and understand the narrative text.

In conclusion, the result of observation is that the students of SMP N 31 Takengon still need many guides for learning writing, especially in writing narrative text using TAI method, because the students still have the obstacle in mastery English language. However, the students' interest enjoyed and can increase students writing.

\subsection{The Result of Test}

For collecting data in this research, the writer used a test. And then, the writer wants to describe the students' scores, the following table is the score of pre-test and post-test in experimental and control classes:

a. The result of the students' score of the pre-test and post-test in the experimental class is as follow:

Table 1. The score of the experimental class

\begin{tabular}{llrr}
\hline No & Students Name & Pre-test & Post-test \\
\hline 1 & ASN & 60 & 70
\end{tabular}




\begin{tabular}{llll}
2 & AT & 65 & 72 \\
3 & EF & 70 & 75 \\
4 & ES & 60 & 79 \\
5 & EP & 55 & 69 \\
6 & IR & 55 & 65 \\
7 & MM & 65 & 72 \\
8 & NW & 70 & 75 \\
9 & MC & 60 & 65 \\
10 & PA & 55 & 65 \\
11 & RH & 55 & 75 \\
12 & RT & 65 & 70 \\
13 & RT & 60 & 69 \\
14 & RH & 65 & 75 \\
15 & RP & 60 & 70 \\
16 & WR & 55 & 75 \\
\hline & Total & 975 & 1138 \\
\hline & Average & 60,93 & 71,12 \\
\hline & Max & 70 & 79 \\
\hline & Min & 55 & 65 \\
\hline
\end{tabular}

From the table above, the pre-test score is 975 , and the post-test is 1138 . So the result in experimental class in the post-test that almost students got very well score than in pretest.

b. The result of the students' score of the pre-test and post-test in the control class is as follow:

Table 2. The score of the control class

\begin{tabular}{llrc}
\hline No & Students Name & Pre-test & Post-test \\
\hline 1 & AP & 55 & 60 \\
2 & AP & 60 & 62 \\
3 & DP & 63 & 65 \\
4 & AW & 60 & 60 \\
5 & FD & 62 & 62 \\
6 & HA & 65 & 72 \\
7 & IY & 55 & 60 \\
8 & MI & 60 & 62 \\
9 & MS & 50 & 60 \\
10 & LM & 55 & 60 \\
11 & LH & 59 & 65 \\
12 & PA & 55 & 65 \\
13 & RF & 60 & 65 \\
14 & SD & 65 & 70 \\
15 & WY & 65 & 70 \\
16 & YM & 55 & 60 \\
\hline & Total & 949 & 1021 \\
\hline & Average & 59,31 & 63,81 \\
\hline & Max & 65 & 70 \\
\hline & Min & 55 & 62 \\
\hline
\end{tabular}


From the table above, the pre-test score is 949, and the post-test is 1021 . The result in control class is not good, because just a view of students in control class got very well score than in pre-test.

After finding the pre-test and post-test results, the researcher wants to analyze the data using the t-test formula. To know the difference between the classes, the researcher used a comparative analysis technique between the two classes by applying the t-test formula as follow:

Table 3. The difference score of pre-test and post-test of experimental class

\begin{tabular}{llcccc}
\hline No & Students & Pre-test & Post-test & Deviation $(\mathrm{d})$ & Score Deviation $\left(\mathrm{d}^{2}\right)$ \\
\hline 1 & ASN & 60 & 70 & 10 & 100 \\
2 & AT & 65 & 72 & 7 & 49 \\
3 & EF & 70 & 75 & 5 & 25 \\
4 & ES & 60 & 79 & 19 & 391 \\
5 & EP & 55 & 69 & 9 & 81 \\
6 & IR & 55 & 65 & 10 & 100 \\
7 & MM & 65 & 72 & 7 & 49 \\
8 & NW & 70 & 75 & 5 & 25 \\
9 & MC & 60 & 65 & 5 & 25 \\
10 & PA & 55 & 65 & 7 & 49 \\
11 & RH & 55 & 75 & 20 & 25 \\
12 & RT & 65 & 70 & 5 & 49 \\
13 & RT & 60 & 69 & 9 & 100 \\
14 & RH & 65 & 75 & 10 & 100 \\
15 & RP & 60 & 70 & 10 & 400 \\
16 & WR & 55 & 75 & 20 & 123 \\
\hline \multicolumn{7}{c}{ Total } & 975 & 1138 & 158 & \\
\hline
\end{tabular}

Based on the data above, the pre-test result is 975 with the mean 60,93 and the posttest 1138 with the mean of 71,12 . While for deviation is 158 with the mean 9,87 and the standard deviation is 1968 with a mean of 123 . This data can be analyzed in the formula below to know the deviation score in the experimental class.

$$
\begin{aligned}
\mathrm{M}_{\mathrm{x}} & =\frac{\sum x}{N x}=\frac{158}{16}=9,87 \\
\mathrm{X}^{2} & =\sum_{X} 2-\frac{\left(\sum X\right)^{2}}{N x} \\
& =1968-\frac{(158)^{2}}{16} \\
& =1968-\frac{24964}{16} \\
& =1968-1560 \\
& =408
\end{aligned}
$$


The result above show deviation standard of the experimental class is:

$M_{x}=9,87$

$\mathrm{X}^{2}=408$

Table 4. The difference score of pre-test and post-test of control class

\begin{tabular}{lccccc}
\hline No & Students Name & Pre-test & Post-test & Deviation $(\mathrm{d})$ & Score deviation $\left(\mathrm{d}^{2}\right)$ \\
\hline 1 & AP & 55 & 60 & 5 & 25 \\
2 & AP & 60 & 62 & 2 & 4 \\
3 & DP & 63 & 65 & 3 & 9 \\
4 & AW & 60 & 60 & 0 & 0 \\
5 & FD & 62 & 62 & 3 & 9 \\
6 & HA & 65 & 72 & 7 & 49 \\
7 & IY & 55 & 60 & 5 & 25 \\
8 & MI & 60 & 62 & 2 & 4 \\
9 & MS & 50 & 60 & 10 & 100 \\
10 & LM & 55 & 60 & 5 & 25 \\
11 & LH & 59 & 65 & 6 & 36 \\
12 & PA & 55 & 65 & 10 & 25 \\
13 & RF & 60 & 65 & 5 & 25 \\
14 & SD & 65 & 70 & 5 & 25 \\
15 & WY & 65 & 70 & 5 & 25 \\
16 & YM & 55 & 60 & 5 & 306,37 \\
\hline \multicolumn{7}{c}{ Total } & 949 & 1021 & 78 & \\
\hline
\end{tabular}

Based on the data above, the pre-test result is 949 with the mean of 63,81 and the post-test 1021 with the mean of 63,81 . While for deviation is 78 with the mean 4,87 and the standard deviation is 486 with the mean 30,37 . This data can be analyzed in the formula below to know the deviation score in the control class.

$$
\begin{aligned}
\mathrm{M}_{\mathrm{y}} & ={ }^{\frac{\sum y}{N y}}=\frac{78}{16}=4,87 \\
\mathrm{Y}^{2} & =\sum_{Y} 2-\frac{\left(\sum y\right)^{2}}{N y} \\
& =486-\frac{(78)^{2}}{16} \\
& =486-\frac{6084}{16} \\
& =486-380 \\
& =106
\end{aligned}
$$

The result above show deviation standard of the control class is:

$\mathrm{M}_{\mathrm{x}}=4,87$

$X^{2}=106$ 


\subsection{Data Analysis}

Based on the data analysis from the students score at experimental class and control class, get the result as:

$$
\begin{aligned}
\mathrm{M}_{\mathrm{x}} & =9,87 \\
\mathrm{M}_{\mathrm{y}} & =4,87 \\
\mathrm{X}^{2} & =408 \\
\mathrm{Y}^{2} & =106 \\
\mathrm{~N}_{\mathrm{x}} & =16 \\
\mathrm{~N}_{\mathrm{y}} & =16 \\
\mathrm{~T} & =\frac{M_{X}-M_{y}}{\sqrt{\left[\frac{\left.\Sigma_{X^{2}}+\Sigma_{Y^{2}}\right]}{n_{2}+n_{y}-2}\right]\left[\frac{1}{n_{x}}+\frac{1}{n_{y}}\right]}} \\
& =\frac{9,87-4,87}{\sqrt{\left[\frac{406+106}{16+16-2}\right]\left[\frac{1}{16}+\frac{1}{16}\right]}} \\
& =\frac{5}{\sqrt{\left[\frac{512}{80}\right]\left[\frac{2}{16}\right]}} \\
& =\frac{5}{\sqrt{[12,06][0,25]}} \\
& =\frac{5}{\sqrt{[3,015]}} \\
& =\frac{5}{1,736} \\
& =2,88
\end{aligned}
$$

\section{Note}

$\mathrm{T}=\mathrm{t}_{\mathrm{obs}}$

$\mathrm{M}_{\mathrm{x}}=$ mean of $\mathrm{EC}$

$\mathrm{M}_{\mathrm{y}}=$ mean of $\mathrm{CC}$

$\mathrm{X}^{2}=$ deviation score of EC

$\mathrm{Y}^{2}=$ deviation score of $\mathrm{CC}$

$\mathrm{n}_{\mathrm{x}}=$ sample of EC

$\mathrm{n}_{\mathrm{y}}=$ sample of $\mathrm{CC}$

$\mathrm{x} \quad=\mathrm{EC}$

$\mathrm{y}=\mathrm{EC}$

\subsection{Testing Hypothesis}

The testing hypothesis should know whether the hypothesis is accepted or rejected. In testing the hypothesis, the basic theory that the writer uses is that the hypothesis is accepted if $t_{o b s} \leq t_{\text {table }}$ or the hypothesis is rejected if $t_{o b s} \geq t_{\text {table }}$.

To find $t_{\text {table }}$ we should to know degree of freedom (df). By following the formula:

$$
\begin{aligned}
\text { Df } & =\mathrm{n}_{1}+\mathrm{n}_{2-} 2 \\
& =16+16-2 \\
& =30 \\
\mathrm{~T}_{\text {table }} & =1,60
\end{aligned}
$$

Therefore $t_{\text {obs }} \geq t_{\text {table }}(0,05)$ with the degree of freedom (df) 30 with $2.8 \geq 1.76$ 
Ha: Teaching narrative text using Team Assisted Individualisation (TAI) Method increase students' writing ability.

Ho: Teaching narrative text using Team Assisted Individualisation (TAI) Method does not increase students' writing ability.

Based on the calculation of $t$-test, where the value $t_{\text {obs }} 2.88$ and $t_{\text {table }} 1.60$ or $t_{\text {obs }} \geq t_{\text {table. }}$. So $\mathrm{Ho}$ rejected and $\mathrm{Ha}$ received, for the conclusion is that the team assisted individualization (TAI) method affects writing in the narrative text at SMPN 31 Takengon. Furthermore, team assisted individualization (TAI) is effective and improves the quality of learning for students at SMPN 31 Takengon.

\section{DISCUSSION}

Writing is one of the necessary skills that must be mastery by students. Through writing, students can express their words and communicate with the reader to tell them to write, certainly with good writing, suitable vocabulary, and correct grammatical.

Writing is the most strenuous lesson in the school since the learners have to produce a text by using English, the learners have to write about what they think in their mind and state it on paper by using the appropriate outcome in writing, a teachers must know about the something that needs to write.

Team assisted individualization (TAI) method is one type of cooperative learning method that emphasizes the ability of an individual, where the individual - the individual has different capabilities - different and used in a small group. In small groups of 4-5 people with heterogeneous capabilities, expected between individuals can work together to achieve the study goal.

Applying TAI Method in the learning process in teaching writing gives positive benefits for the students, especially in writing. The students not only learn from the teacher, but the students also can learn from each other. Using the team-assisted individualization (TAI) method, the students can develop the imagination to write something or anything.

Based on the calculation of t-test, where the value tobs 2.88 and ttable 1.60 or tobs $\geq$ ttable. So $\mathrm{Ha}$ is accepted, and Ho rejected, for the conclusion is team assisted individualization (TAI) method has increased writing in the narrative text at SMPN 31 Takengon. Moreover, team-assisted individualization (TAI) effectively improved the quality of learning for students at SMPN 31 Takengon.

\section{CONCLUSION}

Based on the research finding, some conclusions could be taken as summaries of the research. The insvestigator summarizes the result of the research using the team-assisted individualization (TAI) method to increase the students' writing in narrative text. It can be seen from the result of test tobs $>$ ttable value tobs 2.88 and ttable 1,60 or tobs $\geq$ ttable. The team-assisted individualization (TAI) method also helps the students increase imagination and make the students easy to write in narrative text. 


\section{REFERENCES}

Arikunto, Suharsimi. (2006). Prosedur Penelitian Suatu Pendekatan Praktik. Jakarta: Rineka Cipta.

Batubara, M. H., Rahila, C. D. I., \& Rahmadani, P. (2021). An Analysis On The Students' Error In Writing Report Text At Eight Grade Students Of SMP N 6 Timang Gajah. Jurnal As-Salam, 5(1), 10-19.

https://doi.org/10.37249/assalam.v5i1.237

Batubara, M. H., Herwanis, D., \& Safitriana, S. (2021). An Analysis Of Student's Error In Writing Ability Through Descriptive Text Of VII Grade Of SMP N 4 Takengon. Jurnal As-Salam, 5(2), 110-119. https://doi.org/10.37249/assalam.v5i2.276

Boardman, A. (2002). Writing to communicate. New York: Longman.

Brown, H. Douglas. (2001). Teaching by Principles: An Interactive Approach to Language Pedagogy (second edition). New York: Longman.

Dumont, Hanna \& Istance, David \& Benavides, Francisco. (2010). The Nature of Learning: Using Research to Inspire Practice. Paris: Educational Research and Innovation, OECD Publishing. https://doi.org/10.1787/9789264086487-en.

Halliday, M.A.K. (1985). Spoken and Written Language. Victoria: Deakin University.

Harmer, J. (2004). How to teach writing. Essex, UK: Pearson Education.

Istarani. (2011). 58 Model Pembelajaran Inovatif (Reverensi Guru Dalam Menentukan Model Pembelajaran). Medan: Media Persada.

Istarani \& Ridwan, M. (2014). 50 Tipe Pembelajaran Kooperatif. Bandar Selamat, Medan: CV. Media Persada.

Istarani \& Ridwan, M. (2015). Tipe, Strategi dan Teknik Pembelajaran Kooperatif. Medan: Media Persada.

Kusaeri dan Suprananto. (2012). Pengukuran dan Penilaian Pendidikan. Yogyakarta: Graha Ilmu.

Neman, Beth. S. (1989). Writing Efectypely. New York: Harper and Row Publisher Inc.

Nunan, D. (1991). Second Language and Teaching Learning. Boston, MA: Heile and Heinle Publishers.

Nunan, D. (1999). Second Language and Teaching Learning. Boston, MA: Heile and Heinle Publishers.

Nunan, D. (2003). Practical English LanguageTeaching. Singapore: McGrawhill.

Pardiyono. (2007). Pasti Bisa. Teaching Genre-Based Writing. Yogyakarta: CV. Andi Offset.

Slavin R. E. (1997). Cooperative Learning. Second Edition. USA: Allyn \& Bacon. A Simon \& Aschuster Company.

Slavin, R. E. (2005). Cooperative Laerning. London: Allymand Bacon.

Slavin, R. E. (2008). Cooperative Learning: Teori, Riset dan Praktik. Bandung: Nusa Media.

Slavin, R. E. (2010). Cooperative Learning Teori, Riset dan Praktik. Bandung: Nusa Media.

Sugiyono (2009). Metode Penelitian Kuantitatif, Kualitatif dan R\&D. Bandung: Alfabeta.

Tarigan, Henry Guntur. (1994). Menyimak Sebagai Suatu Keterampilan Berbahasa. Bandung: Angkasa.

Ur, Penny. (1996). A Course in Language Teaching: Practice and Theory. New York: Cambridge University Press. 
Wiratno, T. (2003). Kiat menulis karya ilmiah dalam bahasa Inggris. Yogyakarta: Pustaka Pelajar.

Wiratno, T. (2013). Pembelajaran Bahasa Berbasis Teks dan Jenis-Jenis Teks. Makalah pada Sosialisasi Pembelajaran Bahasa Indonesia dalam Implementasi Kurikulum 2013. 